\title{
Representación, fabricación y apropiación de símbolos católicos por el orden republicano en el Distrito del Centro de la Gran Colombia $(1819-1831)^{*}$
}

\section{Representation, Manufacture, and Appropriation of Catholic Symbols by the Republican Order in the Central District of Gran Colombia (1819-1831)}

\author{
María Cristina Pérez Pérez ** \\ (1) https://orcid.org/0000-0002-0610-1705 \\ Universidad Externado de Colombia, Colombia \\ maria.perez@uexternado.edu.co
}

Resumen: Este artículo describe la manera en la que se implementó un nuevo orden político en el Distrito del Centro en la Gran Colombia en las primeras décadas del siglo XIX, por medio de la apropiación de las celebraciones virreinales, las representaciones del rey, las fiestas religiosas, las imágenes y oraciones creadas en la Gran Colombia. La investigación muestra que para la

* Este artículo no contó con financiación para su realización. Una versión preliminar fue presentada en la $5^{\text {a }}$ Cátedra AGN. Fuentes Documentaciones e Investigación. Bicentenario de la Independencia-Colombia, 2019.

** Doctora en Historia. Líneas de investigación: historia cultural y social, historia colonial, historia religiosa, historia de las imágenes.

Cómo citaR: Pérez Pérez, M. C. (2021). Representación, fabricación y apropiación de símbolos católicos por el orden republicano en el Distrito del Centro de la Gran Colombia (1819-1831). Secuencia (110), e1815. DOI: https://doi.org/10.18234/secuencia.v0i110.1815

c) 98

Esta obra está protegida bajo una Licencia Creative Commons Atribución-NoComercial 4.0 Internacional. 
elite política republicana el reconocimiento del Estado no debía instaurarse rompiendo con todos los códigos, las convenciones y los emblemas reconocidos en su sociedad desde el siglo XVI, sino que estos bien podían ser empleados y apropiados con nuevos significados para instituir la fidelidad al nuevo gobierno. Por lo tanto, se busca aportar a la historiografía colombiana y latinoamericana del siglo xIX que se ha cuestionado por un sinnúmero de símbolos de construcción de las nacientes repúblicas, pero desde nociones fundamentales de la historia cultural, como lo son la representación, fabricación y apropiación.

Palabras clave: Gran Colombia; siglo xIx; representación; fabricación; apropiación.

Abstract: This article describes the way a new political order was implemented in the Central District of Gran Colombia in the early decades of the 19th century, through the appropriation of viceregal celebrations, representations of the king, religious festivals, and images and prayers created in Nueva Granada. The research shows that for the republican political elite, recognition of the state should not be established by abolishing all the codes, conventions and emblems recognized in their society since the 16th century and instead should be used and appropriated with new meanings to instill loyalty to the new government. It therefore seeks to contribute to 19th century Colombian and Latin American historiography, which has been questioned by countless symbols of construction of the nascent republics but based on fundamental notions of cultural history such as representation, manufacture, and appropriation.

Keywords: Gran Colombia; XIX century; representation; manufacturing; appropriation.

Recibido: 29 de enero de 2020 Aceptado: 30 de junio de 2020 Publicado: 10 de mayo de 2021

\section{INTRODUCCIÓN}

Tras la batalla de Boyacá el 7 de agosto de 1819, vivida en el cruce del río Teatino en las inmediaciones de Tunja, donde se da la rendición de la división realista y el triunfo de las tropas republicanas neogranadinas, se puede identificar un acontecimiento cumbre símbolo de la libertad en la Nueva Granada (Chicangana-Bayona, 2009b, pp. 69-95). Esta batalla representaba el final de una contienda que había iniciado varios años antes. Desde 1810 y tras la abdicación de Fernando VII, en manos de Napoleón y su hermano José I Bonaparte, las elites criollas en los territorios de ultramar crearon juntas insurgentes y buscaron obtener cierto grado de autonomía con respecto a la junta establecida en la península ibérica. Pero para 1815, con la presencia de diferencias internas y con el regreso de un rey que reclamaba su poder, la discusión se desplazó a las armas y a los campos de batalla (Annino y Guerra, 2005; Gutiérrez Ardila, 2017; Lux Martelo, 2014).

Tras estos acontecimientos, y con las provincias en gran parte divididas, la elite dirigente neogranadina se vio en la necesidad de reforzar en la población -que dejaba de reconocerse entonces en su gran mayoría como vasalla de la monarquía católica, para identificarse ahora como ciudadana de la República- un sentimiento común de identidad, legitimar el presente desde la construcción de un pasado heroico y resignificar los acontecimientos acaecidos en la independencia (König, 1994). Con este propósito fue fundamental la publicación de la Constitución de Cúcuta o la Constitución de la República de Colombia de 1821, inspirada primordialmente por la figura de Simón Bolívar, y que proporcionó un primer intento de organización republicana con la unión de los actuales territorios de Venezuela, Colombia, Ecuador y Panamá, bajo el nombre conocido como la Gran Colombia (1819-1831). ${ }^{1}$

En este contexto para los nuevos dirigentes y amparándose en los leyes de esta Constitución, el reconocimiento de la República no debía instaurarse rompiendo con todos los códigos, las convenciones y los emblemas reconocidos en su sociedad desde el siglo XVI, sino que estos bien podían ser empleados y apropiados con nuevos significados para instituir la fidelidad al nuevo

${ }^{1}$ A través de la Ley del 12 de octubre de 1821, como había sugerido la Constitución de Cucutá, se generan divisiones administrativas, judiciales y militares sobre el territorio neogranadino en tres distritos: el Distrito del Norte (Venezuela), el Distrito del Sur (Quito) y el Distrito del Centro (Nueva Granada). Estos distritos a su vez se dividían en departamentos, provincias y cantanes (Cabrera Hanna, 2019). 
gobierno, a través de las representaciones de batallas, las pinturas de los actores de esta gesta, el lenguaje en los discursos políticos, las obras monumentales históricas, las monedas con símbolos indígenas y los árboles que figuraban la Libertad (König, 1994).

En la historiografía colombiana sobre el siglo xIx, estos símbolos de construcción de la naciente República han sido estudiados de manera detallada por historiadores, historiadores del arte y estudiosos de las ciencias sociales, quienes han destacado cómo la ruptura del lazo político, social y económico con la corona española implicaba la afirmación de una legitimidad propia (Chicangana-Bayona, 2009a; Earle, 2011; König, 1994; Lomné, 1993, pp. 114-135; Museo Nacional de Colombia, 2010). Esta investigación se inscribe dentro de estos estudios y pretende seguir aportando a estas discusiones, así como aquellas publicadas tras la conmemoración de los dos siglos de existía de la Gran Colombia (Echeverri, Ortega y Straka, 2018), destacando aqui el papel de ciertos símbolos, emblemas y distintivos del antiguo régimen y de la Iglesia católica en la instauración del orden republicano.

Así pues, esta investigación busca mostrar cómo se implementa este nuevo orden en ciertos poblados del Distrito del Centro en la Gran Colombia, y en algunos momentos alusiones a otros distritos retomando las celebraciones virreinales, las representaciones del rey, las fiestas religiosas, las imágenes de culto y las oraciones, que ahora además de estar al servicio del culto divino se emplean en este contexto para rendir homenaje a la figura de Simón Bolí var, las campañas libertadoras y el reconocimiento político y religioso de la República.

Es por esta razón, que esta investigación se inscribe dentro de la historia cultural que estudia, entre un sinnúmero de problemáticas, elementos simbólicos que se crean en un contexto histórico particular y analiza su interpretación dentro de los discursos y prácticas culturales, que se pueden encontrar por doquier en la vida cotidiana de una determinada sociedad (Burke, 2006; Chartier, 2005a; Vaifas, 1996). De esta corriente historiográfica se retoman conceptos como apropiación, representación y fabricación, que han sido teorizados y empleados en investigaciones por historiadores reconocidos como Roger Chartier y Peter Burke. La idea de apropiación, en primer lugar, alude a los usos e interpretaciones (conscientes o inconscientes) que les dan los sujetos y los grupos a objetos, ideas o símbolos en prácticas culturales, y que implica necesariamente el surgimiento de una pluralidad de nuevos significados y usos (Chartier, 2005b).
Ahora, el concepto representación, que contiene una definición múltiple y ambigua, es entendido aquí como algo que permite ver una cosa que es ausente y que a la vez resulta ser la exhibición de una presencia, que dentro de una determinada sociedad pueden ser comunes, colectivas, espontáneas y compartidas universalmente. Pero además se retoma la noción representar que significa "tomar el lugar del otro", y que nos permitirá reconocer cómo personajes como Bolívar establecen su imagen buscando sustituir a la del rey (Chartier, 2005b, pp. 35-37; Lomné 1993; Burke, 2003, p. 17; 2006, pp. 97-98). Por último, la noción de fabricación sugiere -como lo señala Burke en su investigación sobre la construcción de Luis XIV de Francia, el rey Sol-, un proceso histórico, social, político y cultural de la creación misma de imágenes de índole interno y externo, que permite identificar la producción de ciertos hitos históricos, sujetos o "grandes hombres", e incluso la construcción simbólica de su autoridad que conlleva a la idea de representación de representaciones (Burke, 2003, p. 19; 2006, p. 111).2

Este artículo se divide en tres partes. En la primera, se describen los primeros actos de imposición de la República sobre la Iglesia, que permiten vislumbrar lo que será la delimitación de estos dos poderes a lo largo del siglo xIx. Pero, además, a través de la metáfora del estado espectáculo empleada por Clifford Geertz (1999), se indican algunas de las estrategias empleadas en la fabricación de la imagen gloriosa y heroica de Simón Bolívar, retomando rituales del antiguo régimen y la efigie del propio monarca español. En la segunda, se muestra cómo en el Distrito del Centro se retoman algunas festividades religiosas marianas (Inmaculada Concepción y la Virgen de Chiquinquirá), teniendo en cuenta la importancia del tiempo religioso, a la vez que se crea un tiempo colectivo mediado por las festividades de corte civil y republicano, destacando la conmemoración de las batallas de la independencia trasformadas en acontecimientos-símbolos después de 1819. En la tercera, se analizan ciertas representaciones visuales (cruces e imágenes de mártires), que fueron resignificadas por las autoridades locales republicanas sin desconocer su papel sagrado dentro del contexto. Pero además se estudia el empleo de oraciones y plegarias religiosas que fueron solicitas por Simón Bolívar para

${ }^{2}$ Es necesario aclarar que, si bien este artículo se inserta dentro de la producción historiográfica y metodológica de la historia cultural, a su vez de forma directa e indirecta se forriográfica y metodológica de la historia cultural, a su vez de forma directa e indirecta se forAnderson (1993). 
conmemorar la gesta independentista, que ya hacían parte de la tradición de lo escrito en la sociedad neogranadina y que ahora se empleaban al servicio del Estado republicano.

\section{ENTRE EL ANTIGUO RÉGIMEN Y LA REPÚBLICA: RELACIONES IGLESIA Y ESTADO}

En septiembre de 1819, el gobernador de la provincia de Cundinamarca, José Tiburcio Echeverri, organizó una majestuosa y solemne festividad para manifestarle a Simón Bolívar y a sus militares reconocimiento por el notorio papel desempeñado en la citada Batalla de Boyacá en agosto de ese mismo año, a través de la entrega de una corona de laurel y cruces con la insignia "Boyacá" inscrita en el reverso. ${ }^{3}$ Pero además se planteó la posibilidad de obsequiar a Bolívar, a quien se le denomina con el título de Libertador, un cuadro con su imagen y la de una india (que sostendría este personaje) que representaría la Libertad. Estos aspectos son importantes y permiten identificar cómo comienza a adquirir relevancia la figura de Bolívar para la República y su reconocimiento en la gesta libertadora, pero también lo serán algunos hechos de esta celebración descritos prolijamente por la Gazeta Extraordinaria de Santafé de Bogotá, número $12 .{ }^{4}$

En la Gazeta se indicaba que, para el ingreso del General, conducido en compañía de José Anzoategui y Francisco de Paula Santander, se elaboró además un paseo monumental, asearon las calles, pintaron las casas y construyeron siete arcos triunfales que engalanaron su ingreso hasta el lugar seleccionado para concluir el recorrido en la catedral mayor de Santafé, en donde lo aguardaban el prelado eclesiástico y su Cabildo, los rectores de la universidad y de los colegios, y los prelados de las órdenes religiosas de la ciudad, es decir, jesuitas, agustinos, dominicos y franciscanos. ${ }^{5}$

${ }^{3}$ Sobre esta misma conmemoración, llevada a cabo el 18 de septiembre de 1819, y publicada en la Gazeta en octubre de ese mismo año, es referida también en la investigación de George Lomné (1993), para explicar los acontecimientos que denominó como "memorias en disputa" " "ll (1993), pa oxplica los a y "el llamamiento a la virtud civil”, esto es, la conjugación de las prácticas políticas y religiosas
de la colonia en el tránsito de la República.

4 "Triunfo de Bolívar", Gazeta Extraordinaria de Santafé de Bogotá, núm. 2, 12 de octubre de 1819, pp. 45-48.

"Triunfo de Bolívar", Gazeta Extraordinaria de Santafé de Bogotá, núm. 2, 12 de octubre de 1819, pp. 45-48.
La descripción de esta festividad es un buen ejemplo de los medios empleados para dar a conocer a la sociedad las principales batallas, rendir homenaje a los personajes más representativos y, principalmente, para instaurar un nuevo orden social, político y religioso concluido el tiempo de las guerras independentistas. Aquí se observan ciertas delimitaciones que comenzaron a generarse con la Iglesia católica, uno de los estamentos más destacados del orden monárquico. Por lo que no es gratuito que el último lugar del recorrido realizado por Bolívar, Anzoategui y Santander fuera en la catedral mayor, en donde esperaban los prelados, rectores y representantes de las órdenes religiosas asentadas en Santafé.

En este acto los prelados no ingresaron junto al nuevo gobierno como usualmente ocurría en las celebraciones del antiguo régimen al lado de los representantes de la monarquía, sino que ahora aguardaban la llegada de los representantes de la República hasta el centro de su autoridad. Con esto, se escenificaba, por un lado, el reconocimiento dentro del órgano eclesiástico del nuevo orden político y, por el otro, se daban señales de lo que sería la división de estos dos órganos de poder. ${ }^{6}$

Ahora bien, ¿por qué la relevancia de esta imposición del Estado republicano de obediencia sobre estos prelados? La Iglesia católica, es necesario recordar, resultaba ser una de las instituciones más importantes del antiguo régimen e incluso participe activa de las batallas militares de estas primeras décadas del siglo XIX. Esta institución se encontraba vinculada a la corona española por el Patronato regio, que consistió en un conjunto de privilegios y facultades especiales que los papas concedieron a los reyes españoles sobre los territorios descubiertos y por descubrir en el siglo XVI, con la expresa condición de establecer iglesias y dotarlas de bienes para el culto devoto (Hera, 1992, p. 16; Pacheco, 1971, p. 56). Esto conllevo a que durante tres siglos los reyes de España se convirtieran en los reguladores y organizadores de la acción religiosa en Tierra Firme, propiciando que se trasplantara gran parte de la organización eclesiástica de la península a las provincias de ultramar (Pérez Pérez, 2015). ${ }^{7}$

6 "Triunfo de Bolívar", Gazeta Extraordinaria de Santafé de Bogotá, núm. 2, 12 de octubre de 1819, pp. 45-48.

7 Con esta potestad los reyes eran los encargados de pagar los viáticos de los eclesiásticos que se trasladaban desde la península ibérica al Nuevo Mundo, la construcción de recintos que para el culto, además de vigilar las prácticas religiosas contrarias al catolicismo (lo que incluía 
Es por esta razón que, desde su ingreso al territorio a través de la imposición de prácticas religiosas y culturales, los eclesiásticos habían marcado el tiempo social y político de la sociedad neogranadina. Por lo que las autoridades republicanas reconocían el significativo poder que ejercían en el pueblo llano las órdenes religiosas, en especial en aquellas zonas apartadas de los centros de poder donde los clérigos resultaban ser el único órgano de gobierno, como ocurría en varios distritos cercanos al puerto de Cartagena, la Guajira y Santa Marta (Herrera Ángel, 2014, pp. 261-325).

Pero además su participación en este contexto político y social fue de vital importancia, como lo muestra Iván Darío Toro Jaramillo (2008) en su investigación sobre la participación activa del clero en las luchas de Independencia en la Nueva Granada. Su trabajo describe varios casos en los que, por una parte, un número importante del clero estuvo a favor de transitar hacía un nuevo gobierno, participando de manera activa y directa promoviendo el nuevo ordenamiento jurídico. Pero también se destacan otro conjunto de eclesiásticos que decidieron permanecer fieles a la corona, como también lo hicieron algunas provincias dentro del territorio neogranadino, oponiéndose explícitamente a la emancipación por el juramento de fidelidad y doctrinas seculares de obediencia a las legítimas autoridades, es decir, a la corona (Toro Jaramillo, 2008 pp. 119-120). Esto, sin duda, muestra la profunda inserción de la Iglesia y del clero, incluso de los mismos feligreses movidos por estos, en los procesos que se vivían por la sociedad neogranadina que, como lo recuerda Martha Lux Martelo (2014), se caracterizaron después de 1815 y hasta 1819 por dos formas de gobierno políticos: el monárquico y el republicano. ${ }^{8}$

Por esto no resulta extraño que desde 1824 se presentaran discusiones por la posible aprobación del Patronato republicano y que el 24 de enero de 1828 el presidente Simón Bolívar y su secretario del Interior, José Manuel Restrepo, firmaran un decreto sobre el juramento de posesión de obispos y arzobispos, apelando a las jurisdicciones políticas del Patronato que el gobierno

a grupos herejes, protestantes, judíos, batistas e incluso esclavos), a través de un dispositivo social como lo era el Santo Oficio de Inquisición (Pérez Pérez, 2015, pp. 1-61).

${ }^{8}$ Lux Martelo (2014, pp. 19-67) muestra que el rechazo al orden social colonial llevó que se entremezclaran las distintas posiciones de la elite, los movimientos de corte popular, y los debates en contra de los sistemas monárquicos y republicanos. Esto llevó a que dentro gobierno, pues entre 1816 y 1821 estos dos ordenes estuvieron presentes de manera simultánea, y dentro del marco de acción de hombres y mujeres. constitucional esperaba perpetuar. ${ }^{9}$ Se trataría de un largo proceso en el que sólo hasta 1864 la República pudo asumir de manera oficial funciones jurídicas dentro de la Iglesia católica -similares a las establecidas por la corona-, al aducir el derecho de ejercer este poder como un elemento inherente a su soberanía. Por su parte, la Santa Sede creía que no era conveniente continuar con el Patronato concedido a las monarquías católicas y ahora reivindicado por los estados, inclinándose por la relación directa y sin intermediaciones con las iglesias en las nacientes repúblicas, lo que generó desde los primeros años de vida independiente serias discrepancias que se hacían presentes incluso desde los pulpitos (Cortés Guerrero, 2014; Vera Prada, 2004; Saranyana, 2008; Villegas, 1997).

Unos cuantos eclesiásticos, por ejemplo, aprovecharon las celebraciones de sus parroquias y las fiestas de los santos patronos para realizar proposiciones antipolíticas en contra del Patronato republicano, en las que si bien se promulgaban abiertamente elogios a los españoles por trasladar la religión católica, también se apelaba a un gobierno directo por el pontífice en Roma, como parece ser el caso del sermón de fray Juan España, proferido en la festividad de la iglesia de la Merced en el Distrito del Sur en $1828 .{ }^{10}$ Mientras que, por el contrario, personajes como José María Ortega, gobernador de la provincia de Tunja, dan cuenta en comunicaciones escritas al secretario del Interior y Justicia, Estanislao Vergara, del patrocinio eclesiástico a la República con rogativas y sermones para persuadir al pueblo tanto de la importancia del Estado, como del necesario reconocimiento de la jefatura de Bolívar por parte de la Iglesia, los clérigos y, por supuesto, los feligreses en $1820{ }^{11}$

Este reconocimiento estuvo precedido no sólo por los debates en la relación Estado-Iglesia expresadas en las discusiones sobre el Patronato regio y la importancia concedida al republicano, sino además por lo que ha denominado el antropólogo Clifford Geertz (1999) como estado espectáculo, en el que a partir de una serie de rituales, actos, ceremoniales e imágenes -evocando lo teatral- se intenta fomentar y escenificar la obediencia dentro de una deter-

${ }_{9}^{9}$ Decreto sobre juramenteo de posesión de arzobispos y obispos, 1828. Fondo Archivo Anexo. Archivo Anexo. Serie Asuntos Eclesiásticos Parroquias (1696/1933). co. AGN. SAA. 11.3.11, ff. 134-135. Archivo General de la Nación (en adelante AGN), Bogotá, Colombia.

${ }^{10}$ Causa seguida contra fray Juan España por el sermón, 1824. República. Negocios-Administr. SR. 71, 9, doc. 112. AGN, Bogotá, Colombia.

${ }^{11}$ Comunicación de José María Ortega a Estanislao Vergara favoreciendo la causa republicana. República, Negocios-Administr: SR. 71, 2, doc. 36. AGN, Bogotá, Colombia. 
minada sociedad. Uno de esos actos de sujeción recaía de manera especial sobre la figura del propio Simón Bolívar, quien pretendía con el fortalecimiento de su imagen visual y física representar lo ausente o "tomar el lugar del otro", en este caso, del rey español que ocupaba el lugar de Dios y, por tanto, poseía la sujeción de la Iglesia (Elliot, 2010, pp. 55-87; Gloël, 2014, pp. 11-28).

El monarca, príncipe o majestad, figuraba y permitía la integración religiosa y política en todas sus posesiones, a la vez que debía asegurar el buen regimiento (distribuir justicia) y mantener la paz. Por su parte los súbditos, en virtud de su fides cristiana, debían conceder permanentemente lealtad al rey pues desobedecerlo implicaba contrariar el orden de Dios (Salazar Baena, 2017). Si bien algunas investigaciones indican que en las nuevas naciones construidas en América resulta evidente que el rey no tendría ni sucesores ni reemplazo y que el mismo régimen republicano sería la consecuencia inevitable de su destitución, no se puede desconocer el lugar que ciertas figuras heroicas -en este caso Bolívar- comenzaron a ocupar, para sustituir simbólicamente la monarquía dentro del imaginario colectivo republicano (Lomné, 1993, p. 132; Majluf, 2013). Para autores como Georges Lomné (2009), en el caso neogranadino, se trataba de una especie de "república imaginada" que recaía sobre Bolívar, quien tenía el rango de "padre de la República", encarnaba la fórmula "existe Bolívar, luego existe la República" y poseía el título honorífico de Libertador en la Gran Colombia. ${ }^{12}$

Este título, considerado como "propiedad de gloria", se concedió por el Congreso de Angostura en cabeza de su presidente, Francisco Antonio Zea, el 6 de enero de 1820, pero por su mención en la Gazeta Extraordinaria podría indicarse que este título se había otorgado un año antes de manera simbólica entre sus contemporáneos. En el decreto que concedía este reconocimiento, se señalaba que sería el epígrafe que Bolívar usaría en los despachos y actas de gobierno, anteponiéndolo al de presidente, y se inscribiría en la elaboración de un retrato que sería colocado bajo el solio del Congreso con la siguiente inscripción en oro: "Bolívar Libertador de Colombia, Padre de la Patria, Terror del Despotismo" ${ }^{13} \mathrm{Al}$ tratarse de un homenaje concedido tras la victoria de la $\mathrm{Ba}-$ talla de Boyacá, también recibieron por este Congreso el distintivo de "Liberta-

${ }^{12}$ Esta asociación con la Libertad se transformaría a los pocos años y, como lo muestra también Lomné (2003), es sustituida por la Paz y la heráldica, que incluso se propuso dentro del proyecto político neogranadino en 1833 .

${ }_{13}$ "El título de Libertador", 1820. En Bolívar (2016, pp. 9-10). dores de Cundinamarca" todos los individuos del Ejército, así como hombres y mujeres que emprendieron o hicieron parte de esta campaña memorable. ${ }^{14}$

Para el fortalecimiento y la circulación de esta imagen de Bolívar como Libertador, se apropiaron rituales festivos y políticos del antiguo régimen, o en lo que Lomné (1993) a denominado la pedagogía cívica (pp. 133-135). Así, resulta claro que el embellecimiento del entorno urbano, el proceso de transformación festiva de la ciudad y la misma construcción de arquitecturas efímeras, situadas en el ingreso de los militares a las distintas ciudades republicanas, hacían parte de las tradicionales entradas de los virreyes -representantes por demás del rey en estos reinos- conmemoradas en los virreinatos del Perú, Nueva España e incluso de la Nueva Granada.

A la llegada de un nuevo gobernante se construían majestuosos arcos triunfales (con los cuerpos, tableros, intercolumnios y bases de distintos tamaños), debido a que se consideraba uno de los acontecimientos más trascendentes en el calendario festivo de los virreinatos, y donde se le rendía homenaje al virrey por el sinnúmero de méritos que le habían permitido adquirir su título (Farré, 2008: Burkholder, 1984, pp. 3-50). Pero también se realizaban con motivo de la jura a un rey, la muerte de un infante o el nacimiento de un heredero real, cuyas celebraciones estaban precedidas por obras teatrales, corridas de toros, pinturas emblemáticas, entradas triunfales, desfiles, música, bailes y comida, que usualmente estaban antepuestas de signos y de alegorías sobre América y Europa (Fajardo de Rueda, 1999).

Por tanto, con la apropiación de estos cortejos se buscaba la autoafirmación de un gobierno desconocido y la creación de nuevas representaciones épicas no sólo usando imágenes y ornatos reconocidos en la sociedad, sino incluso generando procesos de resignificación de estos. Pero no serían los únicos actos empleados en el proceso de creación y fabricación de esta figura. La creación de la imagen pública del Libertador se organizaba conjuntamente desde el centro mismo de su gobierno por la creciente burocracia que lo acompañaba. Una de las estrategias más significativas serían los preparativos por el natalicio de Simón Bolívar, que pueden datarse desde 1819 cuando era general de los ejércitos y su posterior propagación como presidente de la Gran Colombia hasta $18300^{15}$ Para este fin, se realizaban cultos íntimos con

14 "El título de Libertador", 1820. En Bolívar (2016, pp. 9-10).

${ }_{15}$ Fondo Archivo Anexo. Sección Archivo Anexo. Serie Gobierno. Historia. SAA-I.17, 28, doc. 17, fs. 160-164. AGN, Bogotá, Colombia. 
las personas más próximas a Bolívar y con los agentes gubernamentales que conformaban su jefatura, a quienes cada año se les remitía una invitación para participar en la celebración organizada con tal fin. Aunque también de orden público tras ser solicitadas en comunicados oficiales para rememorar el cumpleaños del Libertador y solemnizar misas en su honor, sufragadas por la propia República, por los ciudadanos o por las autoridades de cada territorio. ${ }^{16}$

Aquí puede ser ilustrativo el documento sobre la celebración del natalicio de Bolívar, del 28 de octubre de 1825, en la ciudad de Pasto considerado un bastión realista unos años antes, indicadas por la Intendencia del Departamento de Cauca:

Cumple años del Exmo. Sor. Simon Bolivar Libertador de Colombia y del Peru celebrando en Pasto el 29 de octubre. Este soberano Dia en que vio luz el padre de los héroes, el sublime Simon, ha sido celebrado por todo el vecindario de esta Provi ${ }^{a}$ con transforma de servido y entusiasmo digno del objeto el mas grandioso para los hijos de la patria. Al despectar al aurora entre esperezos de rosa en este risuelo dia, se enarbolo en la plaza mayor el pabellón tricolor con una salva igual de toda la division, $\mathrm{y}$ al son de concertadas nuncias, todos los militares vestidos de grandes uniformes, y tambien entre paisanos de todas las clases, entonaron canciones patrioticas alusivas a nuestra independencia debido a los esfuerzos del angel de la gloria, al Padre de Colombia [...] por la tarde se dio un esplendio convite por el jefe de la plaza, en donde reino la abundancia, la alegria y el bien humor hermandas con la amistad brindando a la vez cada uno por la prosperidad de la Republica, por la conservacion, felicidad y gloria del invicto Bolivar. ${ }^{17}$

En este día, además de lo descrito en estas líneas, el retrato del Libertador fue colocado en la galería del Cabildo, después de ciertos actos de ceremonia "con la decencia y el respecto debidos", como si se tratara de la imagen del mismo Bolívar. ${ }^{18}$ Un cortejo que de manera usual se cumplía con la represen-

${ }^{16}$ Cartas dirigidas a los ministros de Estado, 1830. Fondo República. Sección Negocios-Administr. SR. 71, 5, doc. 118, fs. 721-724; Celebración en Casanare, 1829. República. Historia. SR. 49, 2, doc. 11, f. 1. AGN, Bogotá, Colombia.

${ }_{17}$ Celebración cumpleaños de Bolívar, 1825. República. Historia. SR. 49, 2, doc. 147, f. 809. AGN, Bogotá, Colombia.

${ }_{18}$ Celebración cumpleaños de Bolívar, 1825. República. Historia. SR. 49, 2, doc. 147, f. 809. AGN, Bogotá, Colombia. tación oficial y pública del monarca español que jamás visitó físicamente estos territorios, por lo que su presencia se daba a través de los retratos oficiales enviados desde la metrópoli principalmente pinturas y esculturas, que invadían las calles, plazas y cabildos con ocasión de todo tipo de festejos barrocos (Rodríguez Moya y Mínguez Cornelles, 2012). Por tanto, y al igual que el rey, los cuadros de Bolívar se convirtieron en su presencia efectiva para gobernar o conmemorar su natalicio, al tener la capacidad de presentar públicamente a una persona ausente que se encarnaba de manera visible (Chartier, 1996, pp. 73-101; Venegas Carrasco, 2012, pp. 113-134).

Por tanto, las muestran simbólicas de poder ante la Iglesia, las discusiones por el Patronato regio, la presentación de Bolívar ante los ciudadanos y su propagación consciente, muestran algunos de los medios empleados para glorificar la República y construirla de manera colectiva en las primeras décadas del siglo xIX. A los que se sumarían las fiestas religiosas como se describirá a continuación.

\section{EL TIEMPO RELIGIOSO Y EL TIEMPO POLÍTICO:} LAS CONMORACIONES FESTIVAS

Debe resaltarse, en primer lugar, que las conmemoraciones de culto religioso presentes en los siglos XVI, XVII y XVIII permanecieron en gran medida y sufrieron pocos cambios en las primeras décadas del siglo XIX ¿por qué? La República reconocía que el tiempo religioso vivido a través de estas épocas ("al son de campanas") era asimismo un tiempo colectivo, es decir, un orden concebido y reconocido aún por los ahora ciudadanos. El calendario litúrgico siguió comprendiendo particularmente los días sacros y festivos, que se vinculaban de manera directa con la vida de Cristo (nacimiento y muerte), las devociones marianas, la fiesta de Corpus Cristhi, y la vida de los mártires y santos patronos de las parroquias. Por tanto, se trataba de un calendario cíclico en el que cada acontecimiento definido como religioso se actualizaba en la celebración misma, y fundía a la vez como un instrumento de poder para ofrecer dádivas o castigos a quienes lo incumplían (Henao Vanegas, 2010, pp. 113-118). ${ }^{19}$

${ }_{19}^{19}$ Es necesario aclarar que las apropiaciones y usos de las advocaciones marianas en la República deben estudiarse de manera local como se ha hecho para el periodo colonial, ya que varias de estas no se reconocían en todo el contexto territorial grancolombiano. De ahí que en 
Una de las festividades que justamente continúo teniendo muestras de exaltación religiosa fue la realizada el 7 de diciembre en honor a la advocación y dogma de la Inmaculada Concepción de María, no sólo porque en gran parte del territorio se perpetuaba su fiesta -en especial, en poblados dedicados a su patrocino-, sino además por que fue invocada en el acto de independencia absoluta de España suscrita en Cundinamarca, que se encabezó en "nombre del pueblo, en presencia del Supremo y con los auspicios de la Inmaculada Concepción de María Santísima, Patrona nuestra" en 1813 (Acta de Independencia de 1813-Nariño, 1902). De igual forma se puede observar en 1820 en la comunicación remitida por el entonces vicepresidente de la República, Francisco de Paula Santander, por parte de Joaquín Antonio Nieto, que describía las plegarias realizadas ante esta imagen por el auxilio de la protección a la causa de la independencia. ${ }^{20}$

Este documento muestra cómo la República le proveía a esta advocación y dogma católico un lugar similar al que había tenido en la monarquía católica, que había propiciado su propaganda, culto y defensa al conceder el patrocino de España y de las Indias a María en este ministerio, por medio de reales órdenes que circularon en las provincias del Nuevo Mundo. Esto en el contexto de la Reforma protestante y los postulados de Martín Lutero, que había cuestionado el uso de las imágenes religiosas en los templos y la expansión en el Orbe católico de este dogma, que hacía referencia a la concepción de María en el seno de Santa Ana. La corona española al propagar este dogma, ahora retomado en la Gran Colombia, se apoyaba en las sentencias expuestas de manera pública por el franciscano Duns Escoto en la Universidad de París en el siglo XIV, que sostenía que María estuvo libre de pecado desde el primer momento de su concepción (Warner, 1991; Panizza, 1972; Sebastián, 1985).

De ahí que en acontecimientos republicanos que simbolizaban algún peligro se invocara de manera especial su protección. Uno de los hechos que movió más la fe de los feligreses, que conllevó a solicitar apoyo divino y reconocer la importancia de los milagros, cuestionados en 1623 por el papa Urbano VIII (Rubial García, 2001), fue el atentado del que salió ileso Simón Bolívar el 25 de septiembre de 1828 (conocida como la Conspiración Septembrina),

este apartado sólo se describa la reapropiación de algunas advocaciones marianas y queden otro tanto por ser estudiadas.

${ }^{20}$ Celebración de la Señora de la Limpia Concepción, Patrona y Titular por el auxilio de la Independencia, 1820. Archivo Anexo. Serie Gobierno. Historia. SAA-I.17, 25, doc. 14. AGN, Bogotá, Colombia. en cabeza de Pedro Carujo. Tras las noticias de este hecho, Bolívar además de recibir cartas expresando júbilo por el buen estado de salud por parte de los gobernantes, el apoyo de sus magistrados y el soporte de la policía en Santafé, fue objeto de rogativas perpetuadas por nueve días ante retratos como el de la Inmaculada Concepción y de permanentes actos religiosos en acción de gracias. ${ }^{21}$ Ahora bien, a la par de los homenajes ofrecidos a esta imagen se apropiaron y resignificaron otras festividades de santos patronos y de advocaciones marianas locales, a las que igualmente se le solicitaba realizar rogativas pidiendo la conservación del presidente Bolívar y de sus funcionarios.

Una de las más representativas sería el cuadro de la Virgen del Rosario de Chiquinquirá, que se encontraba bajo la orden dominica, santuario al que se le solicitó incluso un préstamo voluntario en numerario o alhajas preciosas para el mantenimiento de los ejércitos patriotas. Su santuario era uno de más emblemáticos en este territorio y se encontraba en el poblado de Chiquinquirá, en el que se conservaba el mencionado cuadro milagroso que representaba a la Virgen del Rosario, Antonio de Padua y Andrés apóstol (Álvarez White, 1986). El patrocino de esta imagen por parte de las autoridades eclesiásticas y civiles responde al significado mismo que tenía dentro de los feligreses. Esta pintura, que forma parte de las imágenes consideradas dentro del catolicismo como acheropoiéticas, aquellas que, realizadas "sin la intervención de la mano del hombre", se supone guardaban en sí mismas el poder de lo sagrado, y recibía un culto especial por los devotos neogranadinos desde que se conoció la leyenda de la restauración de sus pigmentos milagrosamente a finales del siglo XVI (Vences Vidal, 2009, pp. 97-126).

Asimismo, está claro que, en Chiquinquirá como en todos los centros religiosos similares durante el antiguo régimen y ahora en la República, la imagen por excelencia se convirtió en el centro sacramental del santuario. Los devotos se trasladaban largas distancias para contemplarla, los eclesiásticos acostumbraban a sacarla en procesión ante los infortunios vividos en un poblado, las autoridades eclesiásticas clamaban continuamente por su decoro, las órdenes religiosas pretendían poseer los beneficios que se derivan de su culto, y la sociedad en su conjunto acudía a su protección (Freeberg, 1998, p.

${ }^{21}$ Rogativas tras el atentado de Bolívar. República. Historia. SR. 49, 1, D. 97, ff. 620-641. AGN, Bogotá, Colombia. 
44). ${ }^{22}$ Pero también respondía a una práctica retomada del periodo monárquico donde las imágenes de María y de sus advocaciones tenían una carga política importante, pero también las representaciones de mártires y santas como, por ejemplo, en el caso de Santa Rosa de Lima en el virreinato de Perú para diferentes estamentos sociales (Mujica Pinilla, 2001).

Por lo tanto, la eficacia y el poder de esta imagen, como el de otro tanto invocadas también por los ciudadanos, se debía a la identificación entre aquellos que observaban la imagen (los creyentes) y lo que ella representaba (los objetos de culto), es decir, su vitalidad estaba relacionada con lo que parecía que hacía, con lo que se esperaba que hiciera y con las múltiples expectativas que guardaban los devotos que iban a su encuentro al santuario (Pérez Pérez, 2015, pp. 113-118). Razón por la cual el gobierno republicano encontró en esta advocación local una vitalidad milagrosa, que continuó presente incluso a lo largo del siglo xix y que ha llegado hasta la actualidad (Londoño Botero, 2009, pp. 83-94)

Aparte de retomar estas celebraciones y colocarlas al servicio del fortalecimiento de la República, las autoridades fabricaron un nuevo tiempo festivo, el tiempo republicano, que no excluía al religioso y que, por el contrario, se establecía a través de él. Se trataba de la creación de un nuevo orden colectivo que debía ser socialmente reconocido por los ciudadanos, y se organizaba de manera cíclica al igual que el religioso en tanto sus duraciones se renovaban una y otra vez cada año (Henao Vargas, 2010, pp. 113-118). Pero además en el que se creaba un calendario político fijo para todos los ciudadanos del Estado, que reconocía un sinnúmero de fiestas ideológicas y civiles que debían conmemorarse en todo el territorio. No cabe duda que una de las importantes sería la conmemoración de la Batalla de Boyacá de 1819.

Esta celebración posee varios elementos significativos. Primero, es necesario preguntarse por qué la relevancia de conmemorar esta batalla, que fue incluso igualada por los escritores de la Gazeta Extraordinaria de Santafé a una de las "más brillantes" escenas de Grecia y Roma. ${ }^{23}$ Lo que respondía, como señalan Ricardo del Molino García (2007), al reconocimiento que realizan con frecuencia agentes históricos que buscan en la experiencia y legados de

${ }^{22}$ El uso de las imágenes en el tránsito de la colonia a la República también ha sido estudiado para el caso de Brasil, de manera particular, por José Murillo de Carvalho (1997) en una investigación que resalta, entre múltiples elementos, la construcción de la República-mujer y el papel de la alegoría de Marín.

23 "El título de Libertador", 1820. En Bolívar (2016, pp. 9-10). otros tiempos -en este caso, en el fracaso y las victorias de la antigüedad clásica- identificar los nuevos modelos políticos de nación, Estado y ciudadanía. O como lo sugerido por Tomás Pérez Vejo (2003, pp. 298-300) cuando estudia el caso de Nueva España, la articulación del pasado y del presente dentro de la República buscaba mostrar la existencia de una nación intemporal, que no necesitaba que fuera construida pues existía ya desde el origen de los tiempos. A la vez que esta articulación, que retomaba ciertos símbolos y representaciones de otros periodos históricos, tenía como propósito homogenizar las sociedades heterogéneas y fragmentadas por divisiones étnicas, culturales, legales, entre otras, en los primeros años de establecimiento de la República e incluso a todo lo largo del siglo XIX.

Ahora bien, esta evocación igualmente respondía a que la contienda vivida en Boyacá se identificó como un acontecimiento-símbolo, es decir, un hecho que se convirtió en un emblema colectivo y que luego fue asociado metafóricamente a la terminación de la tiranía española, la libertad y la lucha independentista. Los acontecimientos históricos de este tipo resultan relevantes en tanto permanecen en el tiempo más allá del instante en el que se presentan y hacen referencia a un antes y un después en el flujo de la historia (Beck, 2017, pp. 44-59).

Para este propósito, además serían fundamentales los escritos de José Manuel Restrepo (1858) -que fue diputado al Congreso de Cucutá, secretario del Interior y Relaciones Exteriores y administrador de la Casa de la Moneda en Santafé-, quien después de elaborar un diario político y militar de los acontecimientos acaecidos en 1819, y de compilar documentos y entrevistas a los protagonistas de hechos públicos vividos en la Nueva Granada, escribe la obra titulada Historia de la revolución de la República de Colombia en la América Meridional. Para este autor, como para muchos de sus contemporáneos, su ubicación privilegiada como participante y testigo de los acontecimientos, lo convertía en portador de un tipo de verdad que le permitía combatir los errores y prejuicios de la historiografía europea del momento. ${ }^{24}$

Empero, en este contexto de organización política y militar no sería el único acontecimiento de relevancia que se conmemoraría. La documentación

${ }^{24}$ No obstante, Germán Colmenares (1997) criticó este tipo de acercamiento al pasado por los escritores del siglo xix, indicando que la obra de Restrepo había creado una prisión historiográfica, es decir, estableció un repertorio fijo e inalterable de hechos de la revolución de

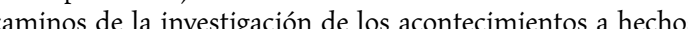
sociales durante casi dos siglos. 
indica que, tras el arribo de generales y soldados de una nueva contienda, se realizaban homenajes y ceremonias por las victorias de los ejércitos republicanos, que adquirían la connotación de nuevos acontecimientos-símbolos que merecían ser reconocidos de manera colectiva. Un ejemplo de esto es el artículo publicado en la Gaceta de Colombia, del 14 de noviembre de 1826, que describía la entrada de Simón Bolívar después de cinco años de ausencia por las campañas militares emprendidas en Perú y Bolivia, en la que nuevamente se describen los actos simbólicos que tuvieron lugar en Santafé (que ahora se denominaría en la Gaceta como Bogotá) y que fueron descritos en el primer apartado de este artículo (Blanco y Azpurua, 1876, pp. 700-701).

En estos homenajes dirigidos a los militares participaban distintos miembros de la Iglesia, lo que permitían lograr una impresión favorable en el público y convertirse en instrumentos claves de autoafirmación. Estas herramientas se componían de actividades que, además de ser recurrentes en la cotidianidad de las ciudades, estaban cargadas de ciertos simbolismos religiosos como la liturgia de la misa -según el rito romano-, conmemorada en honor a las victorias de cada batalla, el ingreso de los generales o cualquier acto consagrado al bien de los ciudadanos y del territorio. Así, pues, una decisión en favor de la República podía evocar la celebración eucarística que era el preámbulo de las festividades locales, que luego se realizaban en las plazas y en las calles de cada poblado, como aquellas conmemoradas en Bogotá, Chocontá, Sesquilé, Guatavita, Guasca, Machetá, Tibirita, Manta, Gachetá, Tausa, Mesa del Carmen, Funeque y Ubaté por la publicación de la Constitución de Cucutá y las juras de fidelidad a la misma en $1821 .^{25}$

Por otro lado, en este calendario republicano que contemplaba lo civil y lo religioso, no sólo los actos emblemáticos de las batallas de la independencia tendrían lugar, también serían relevantes las cofradías y sus festividades en favor de los santos patronos. Las cofradías, organizaciones medievales trasladadas al Nuevo Mundo desde el ingreso de las órdenes religiosas, reunían durante los siglos XVI al XVIII a diversos grupos de españoles, indios y mestizos, que contaban con un espacio particular en los templos y capillas para la exposición de su imagen patronal. Cada una de estas asociaciones poseía la facultad concedida por el arzobispo para aderezar la imagen, decorar el altar, proveerse de cera, encargar efigies, adquirir indumentaria para el altar

${ }^{25}$ Actas y certificaciones de ciudades, municipios y parroquias por publicación de la Constitución, 1821. República. Negocios-Administr. SR. 71, 5, doc. 99. AGN, Bogotá, Colombia. y celebrar su festividad anual, marcando una fuerte distinción entre aquellos grupos que contaban con el apoyo económico de sus cofrades y los que se sustentaban únicamente de limosnas (Pérez Pérez, 2015, pp. 128-130). Por su importancia como instrumento de cohesión social, ya que en su participación se reforzaba el prestigio económico y político de los vecinos de una parroquia, su mantenimiento comenzó a ser parte de las jurisdicciones de la República.

De ahí que, ante instituciones como la Superintendencia y la Tesorería General de Hacienda, se pudiera solicitar a distintas autoridades por los mayordomos de las cofradías aportes del gobierno para celebrar las fiestas al culto de advocaciones marianas; pago de los réditos por administradores de entidades del Estado (como, por ejemplo, el administrador de Tabacos) infringidos por varios meses; licencias para la venta de propiedades (solares y casas) legadas por cofrades o devotos a la imagen principal de la comunidad; solicitud del dispendio de plata para ciertas cofradías apelando a la tradición de los reyes de España, quienes solían patrocinar el culto de advocaciones locales como la de la Virgen del Topo; entrega de cuentas y relación jurada sobre los caudales correspondientes a las cofradías por el ingreso de réditos, así como de los comprobantes de gastos de las ceremonias festivas, cuidado y culto de imágenes patronales. ${ }^{26}$

Este último punto, sobre la devoción de efigies católicas, resultaba ser un tema de gran relevancia, en tanto el uso de representaciones visuales, de rogativas y oraciones a los santos fueron otras de las herramientas elegidas para establecer dentro de la sociedad el reconocimiento de la República.

\section{IMÁGENES Y PLEGARIAS: APROPIACIÓN DE LO RELIGIOSO EN LO POLÍTICO}

El significado de las representaciones visuales ha sido abordado por varios historiadores, interesados en identificar y conocer aquellos procesos de pro-

${ }^{26}$ Solicitud del doctor Rufino Cuervo, 1821. República. Sección Peticiones-Solicit. SR 75, 5, doc. 37; Maximiano Ochoa (mayordomo de la cofradía de la iglesia de San Mauricio) suplica se exija al administrador de Tabacos le haga llegar los réditos vencidos de dicha renta 1821. República. Peticiones-Solicit: SR. 75, 17, doc. 6; Petición de 100 ducados por Fernando Caicedo, 1822. República. Peticiones-Solict. sR. 75, 3, doc. 41, Cuenta ordenada y relación jurada Archivo Anexo. Grupo II. Diezmos. 15.16.2. AGN, Bogotá, Colombia. 
ducción y circulación de los emblemas republicanos. Uno de ellos es Yobenj Aucardo Chicangana-Bayona, quien ha mostrado la transformación del sistema político que condujo a un nuevo lenguaje en el ámbito mismo de la creación de imágenes y de la fabricación de un nuevo programa iconográfico que servía a los propósitos del Estado. Este sistema visual tenía como principal referente los retratos de santos, reyes, virreyes, bachilleres y abadesas del siglo XVIII, de los que la República apropio algunos elementos convencionales como las posturas de los personajes centrales, el uso de la luz, la utilización de objetos y el tamaño de los cuadros (Chicangana-Bayona, 2011, pp. 525-554).

Aunque estas no serían las únicas representaciones resignificadas y apropiadas para transmitir ideas políticas en la instalación de la Gran Colombia. De ahí la importancia de las cruces entregadas en el citado homenaje del gobernador de la provincia de Cundinamarca, José Tiburcio Echeverri, a Bolívar, Anzoategui y Santander, así como a los soldados que lo acompañaron en la compaña libertadora en Boyacá. La cruz se consideraba el principal símbolo del cristianismo, transformado iconográficamente a través de los siglos por los artífices de imaginería y poseedor de múltiples significados para el orbe católico (Sanz, 1950, pp. 247-260).

Uno de ellos aludía a este signo como un instrumento de la crucifixión, la muerte y la resurrección de Cristo. Este tipo de imágenes se encontraban presentes en todas las actividades religiosas del cristianismo y ocupaban múltiples espacios de la vida cotidiana de los creyentes: se sacaba en las procesiones de Semana Santa, se exponía en el altar mayor durante la celebración de la misa, se llevaba en el pecho por los eclesiásticos, se presentaba a los moribundos para que expiaran sus pecados, y, de hecho, se utilizaba en las obras teatrales que se solían organizar en remembranza de la Pasión y Resurrección de Jesús en Semana Santa. ${ }^{27}$

Esto explica también el uso en este contexto político de imágenes alusivas a la vida de Cristo, que fueron retomadas para proteger a la nación, bendecir al gobierno, proteger a los militares y resguardar a los feligreses. Dos ejemplos pueden describir este proceso de apropiación a principios del siglo xIX. Por un lado, se encuentra la efigie del Nazareno, una imagen de bulto

${ }^{27}$ Inventario de la iglesia de Talca y su anexo Magdalena. Magdalena, 1789. Colonia. Sección Fábrica de iglesias. Rollo 1, orden, 29, fs. 925-955; Inventario Compañía de Jesús. Pauto, 1767-1768. Colonia. Fábrica de iglesias. Rollo 17, orden, 10, fs. 86-112; Inventario de los bienes eclesiásticos. Espinal, 1770. Colonia. Fábrica de iglesias. Rollo 17, orden, 10, fs. 113-118. AGN, Bogotá, Colombia. de la iglesia de San Agustín, que fue condecorada con el grado de general de los ejércitos de Cundinamarca por Antonio Nariño. Esta escultura, que ha sido estudiada por Juan Ricardo Rey-Márquez (2010, pp. 2-36), acompañó numerosas procesiones en la fiesta del "Dulce nombre de Jesús", el 17 de enero de 1813, con el propósito de socorrer y proteger la Campaña del Sur por medio de procesiones (acompañadas de religiosos y feligreses) desde la iglesia de San Agustín hasta la catedral mayor. Por otro lado, se encuentra la efigie del Señor del Despojo -representación que alude a una de las escenas del viacrucis, cuando Jesús es despojado de sus vestiduras- de la ermita de las Cruces de Santafé, una advocación que contaba con cierto reconocimiento entre los fieles a finales del siglo XVIII, y que en 1813 fue reconocida e invocada como patrona del Regimiento de Milicias de Infantería de Santafé. ${ }^{28}$

Del mismo modo, es importante reconocer la apropiación de mártires a los que ahora acudía la República, cuando se necesitaba cierta ayuda milagrosa, o para transmitir las ideas en la instalación de las juntas de Gobierno. Una de las más representativas y de las que varios investigadores han hecho alusión, será Santa Librada a quien se le concedió como fecha de celebración el 20 de julio, y cuyo símbolo de la nueva nación data del 19 de julio de 1813, cuando incluso participaron de su conmemoración personajes como Antonio Nariño (Rey-Márquez, 2010, pp. 10-11).

Más allá de esto, lo que resulta significativo de esta imagen es que no sólo su devoción circuló por el territorio, fue objeto de celebraciones eclesiásticas y estuvo presente en los altares de varios templos cuando se requería su auxilio, sino que además su presencia se hizo visible en las propias construcciones arquitectónicas republicanas. Así, pues, un hospital en Santafé y colegios en la ciudad de Cali, perteneciente a la provincia de Popayán, se erigieron llevando su nombre y se colocaron bajo su amparo y protección entre 1822 y 1823. Con esto, Santa Librada recibía los respectivos honores por parte del Estado y se insertaba en el entorno cotidiano de la sociedad, en donde comenzaba a tener reconocimiento y era apropiada por los feligreses republicanos. ${ }^{29}$

Por último, otro de los medios en los que es posible identificar símbolos de la Iglesia católica en la implantación de este nuevo orden es el apoyo

${ }^{28}$ Iglesia del Señor de Despojo. Fondo Colonia. Sección Miscelanea. cs, 39, 128, doc. 2, fs. 63-69. AGN, Bogotá, Colombia.

29 Colegio de Santa Librada a Bolívar, 1829. República. Historia. SR. 49, 2, doc. 60 , fs. 302 305. AGN, Bogotá, Colombia. 
de las órdenes religiosas en la elaboración de oraciones o plegarias, que luego eran impresas y circulaban por el territorio para ser empleadas en las fiestas patrias. Un ejemplo de esto se encuentra en un documento de 1819, en el que se indica la solicitud remitida por Simón Bolívar a la comunidad de agustinos, para que crearan una plegaria alusiva al parecer a los logros obtenidos en la independencia. Hasta este momento se desconoce el contenido de esta oración, ya que dentro del legajo se indica que no fue remitida por que se encontraba en "revisión previendo no tener errores". ${ }^{30}$ No obstante, tampoco se trataría de una práctica nueva, la Iglesia católica había empleado durante décadas este tipo de escritos con distintos propósitos. Por ejemplo, para agradecer públicamente sobre un milagro o un beneficio recibido para todos los feligreses, como la elaborada por el canónigo magistral de la catedral de Santafé en agradecimiento al rey por la producción de vacunas contra la viruela y su distribución en la Nueva Granada en $1805^{31}$

Ahora bien, ¿cuál era el objetivo de este tipo de textos? Estas oraciones se enmarcaban en una tradición amplia de lo escrito, que había acompañado a estas sociedades por el papel proporcionado por la Iglesia y que serían desde aquel momento empleadas al servicio del Estado. En este contexto, existía además el reconocimiento de un grupo de letrados que prestaban su servicio a la difusión de la fe, a través de la elaboración de plegarias, novenas, partituras, entre otros escritos. Se trataba de párrocos de los templos que cuestionaban imágenes consideras prodigiosas, clérigos diocesanos que dedicaban epístolas a ciertas advocaciones marianas o religiosos pertenecientes a las órdenes religiosas. También cabe la posibilidad de que estos textos se elaboraran por personas laicas vinculadas de una $\mathrm{u}$ otra forma al estamento eclesiástico, como miembros de las cofradías, congregaciones o gremios creados en honor a los santos mártires. ${ }^{32}$

${ }^{30}$ Comunicación sobre la oración encargada por Simón Bolívar, 1819. Archivo Anexo. Serie Gobierno. Historia. SAA-I.17, 26, doc. 47. AGN, Bogotá, Colombia.

${ }^{1}$ Solicitud de licencia para publicar oración por la importación y propagación de vacuna, 1805. Colonia. Historia-Eclesiástica. sc. 30, 13, doc. 16, fs. 778-781. AGN, Bogotá, Colombia. 32. Colonia. Historia-Eclesiástica. sc. 30, 13, doc. 16, fs. 778-781. AGN, Bogotá, Colombia. Theosoro escondido en corazón de Jesús, por un Devoto del mismo coraźn. En Sta. Fe de Bogotá Theosoro escond do en corazón de esús, por un Devoto del mismo corazón. En Sta. Fe de Bogotá en la Imprenta de la Compañía de Jesús, 1739; y Novena de la Santísima virgen, y madre de Dios del Carmen, María Santísima. Sácala a la luz la Congregación de la Corona de Nuestra Señora del Carmen, sita en el Colegio de San Alberto a las Sras. Devotas y congregados. Con licencia:
impresa en Sevilla en la Imprenta las siete Revuelta, Santafé, 1778.
Los autores -término que comenzaba a ser utilizado cada vez con mayor frecuencia en las fuentes de la época- tenían conocimientos en todo lo relacionado con la teología y escolástica al educarse en los colegios jesuitas y dominicos, conocían la vida de los santos custodiados de sus templos, y en algunos casos se limitaron a traducir del latín al castellano manuscritos, resumir grandes obras a pequeños formatos o componer homilías apoyados en libros que circulaban desde la península. ${ }^{33}$

Las oraciones del tipo solicitadas por Bolívar, después de ser escritas por uno de estos autores, se revisaban por un hombre de letras, se imprimían o copiaban a mano, y se distribuían en diferentes espacios con el propósito de ser leídas en voz alta. Esto era fundamental en una sociedad mayoritariamente iletrada, que estaba acostumbrada a las homilías, a los sermones desde el púlpito, y a repetir las oraciones hasta asimilarlas y luego reproducirlas. Ahora bien, el cuidado del agustino de no remitir a Bolívar el documento hasta revisarlo nuevamente para percatarse de no tener errores, respondía a que desde finales del siglo XVIII se habían establecido numerosos controles por las autoridades eclesiásticas y civiles de los escritos que circulaban y eran producidos por legos o eclesiásticos.

En primer lugar, el procurador general leía el borrador confirmando que se encontraba conforme a los tratados promulgados por el catolicismo, por lo que generalmente esta función se cumplía por un eclesiástico vinculado a la orden jesuita, dominica o agustina. En segundo lugar, los escritos se calificaban por letrados vinculados directamente con la Real Audiencia, quienes reconocían si las obras contenían elementos opuestos a la regalía. Por tanto, revisaban que lo escrito no contrariara el derecho papal concedido a través del Patronato regio y no cuestionara el papel de la corona española en las Indias. ${ }^{34}$

Un tercer paso consistía en presentar el escrito ante el arzobispado con el objetivo de ser concedida oficialmente la licencia de impresión. Los obispos, en compañía de clérigos doctos, revisaban que los contenidos efectivamente no presentaran ideas en contra de Dios y ni del Rey. En tal sentido, al

${ }^{35}$ El cura de Mariquita solicita imprimir una novena en la hora de San Joaquín y Santa Ana, compuesta por él, Santafé, 1801. Colonia. Misceláneas. Imprenta. T. 10, N. 3, fs. 111-116. Ana, compuesta por él,

${ }^{34}$ Groot y Vargas Felipe hace la presentación de una novena de Santa Bárbara, Santafé, 1755. AGN, Colonia. Misceláneas. Conventos. Rollo 004, Orden 75, fs. 852-872. AGN, Bogotá, Colombia. 
comprobarse que los autores procedían con piedad, se entregaba un documento firmado por el arzobispo y certificado por la Iglesia católica, que era llevado a las prensas para respaldar la impresión. En caso contrario, las autoridades solicitaban modificar el contenido del escrito presentado, cambiar los apartados que no cumplían con lo requerido, o simplemente destruir las obras que contrariaban lo estatuido. ${ }^{35}$ Por estas razones, ciertas novenas, homilías y oraciones, a pesar de ser elaboradas para dar gracias por un favor recibido, en honor a un santo o una advocación mariana, a una pintura o una escultura milagrosa, no fueron impresas como era el objetivo de sus devotos autores. Pero además por que se consideraba que la lectura ya no estaba inscrita en el texto mismo, sino además en sus lectores que le otorgaban distintas significaciones, un proceso resaltado ampliamente por Roger Chartier (1993), quien considera que la lectura está limitada por los códigos y las convenciones que rigen las prácticas de una comunidad, pero además por las formas discursivas y materiales de los textos leídos y de las posiciones de los autores.

Esto explica el interés de las autoridades por revisar los contenidos y de los propios autores, como lo indica expresamente el religioso de la orden agustina a Simón Bolívar y posteriormente a Francisco de Paula Santander, por fijar un sentido y enunciación a su interpretación para forzar la lectura, aunque en realidad la recepción siempre invitaba, desplazaba y distorsionaba (Chartier, 2005a, p. 21). A esto se suma que, la sociedad de estas primeras décadas del siglo xix, había iniciado un proceso años atrás, en el que se abogaba por prácticas más austeras, íntimas, sobrias y recatadas de los fieles devotos, frente a la excesiva importancia que se había dado por décadas al culto, a los santos e incluso a las manifestaciones religiosas a través de los rezos. Se planteaba la importancia de que la religiosidad y algunas de sus prácticas se realizarán ahora en lugares más íntimos y particulares como los hogares. ${ }^{36} \mathrm{Lo}$ que explica también la importancia en este contexto de las oraciones que se podían cargar, cuidar y recitar en espacios públicos e íntimos, pero que además solían llevarse a pesar de las censuras de la Iglesia guardadas en alguna parte del cuerpo, por la creencia que simples escritos, pedazos del evangelio u oraciones de los santos poseían igual poderes milagrosos (Pérez Pérez, 2015).

${ }^{35}$ León Antonio, cura de Suta, solicita licencia para imprimir la novena de la Inmaculada Concepción, Santafé, 1800. Colonia. Misceláneas. Conventos. Rollo 001, orden 25, fs. 495-501. Concepción, Santafé, 1800 , Bogotá, Colombia.

${ }_{36}$ Sección Colonia. Fondo Mortuorias. T. 243, doc. 514, fs. 11r-23r; t. 266, doc. 5632, f. 3v t. 257, doc. 5563, f. 4r. Archivo Histórico de Antioquia (em adelante AHA), Medellín-Colombia.
Ahora bien, teniendo en cuenta lo expuesto, y a pesar de no tener certeza de lo que indicaba la plegaria, resulta claro que este tipo de escritos también tuvieron un lugar destacado dentro de la fabricación misma de los símbolos de la República. Esto lo confirma igualmente la documentación de la época. Durante el aniversario de la Batalla de Boyacá en 1820, se repartieron ejemplares de una oración que fue pronunciada por Manuel Fernández Saavedra en un acto público en conmemoración de la independencia, y que posiblemente puede tratarse de aquella solicitada por Simón Bolívar. Sin importar esto, Fernández Saavedra en esta plegaria daba a conocer la historia de la nación, las alegorías de la República, las batallas referidas a acontecimientos-símbolos y el homenaje rendido a los próceres, como se haría con los cuadros del Libertador.

\section{CONCLUSIONES}

Esta investigación ha mostrado cómo durante las primeras décadas del siglo XIX en el Distrito del Centro de la Gran Colombia se construyó un estado espectáculo donde la Iglesia, los religiosos y los propios feligreses desempeñaron un papel fundamental. En este contexto, se retomaron varios elementos pertenecientes al ámbito religioso implantados en el ámbito colectivo, por medio del uso símbolos festivos del antiguo régimen, el mantenimiento de solemnidades religiosas, la imposición de celebraciones festivas políticas, así como el uso de imágenes de culto, la creación de la figura de Simón Bolívar y la solicitud de plegarias a las órdenes religiosas. Para ello, los miembros de la República emplearon estrategias desde la creación de nuevas representaciones, la fabricación de acontecimientos y apropiación de símbolos, que se establecían desde el Estado a las estructuras medias de la República hasta llegar hasta los ciudadanos.

En cuanto a la noción de representación se hizo un especial énfasis en la idea de representar cómo tomar el lugar del otro, una estrategia empleada por el Estado y sus magistrados para resaltar la imagen del presidente de la República, Simón Bolívar. También representaciones que estaban presentes en ciertos objetos como pinturas, monedas, escritos o plegarias, que llevan la imagen del Libertador y a veces su nombre. La noción de fabricación como un proceso de creación de nuevos acontecimientos-símbolos, como los que aludían a las batallas de la independencia y que recaían de manera especial en grandes 
hechos como la Batalla de Boyacá. Pero además la fabricación de un nuevo tiempo ahora de corte político que, sin desligarse completamente del religioso, crea dentro de los ciudadanos nuevas solemnidades y fechas de conmemoración. La noción de apropiación, por último, donde se aludió a una serie de objetos, símbolos, figuras, escritos, plegarias y festividades que el Estado, las órdenes religiosas y ciertos gobernantes retomaron de prácticas sociales, culturales y políticas de los siglos XVI, XVII y xVIII, para darle una pluralidad de nuevos y renovados significados a principios del siglo XIX.

Ahora bien, este artículo no logra responder cómo la sociedad republicana, es decir, los ciudadanos, recibieron estas formas de representación y fabricación, o cómo se apropiaron en la cotidianidad y a partir de qué tipo de prácticas estos nuevos símbolos. Esto tiene que ver, en gran medida, con las propias limitaciones de la documentación consultada hasta este momento que muestra generalmente solicitudes, peticiones o pleitos desde el Estado, los gobernantes, o el clero, y muy poco sobre la sociedad que finalmente los recibía. No obstante, a pesar de este desconocimiento, de su asimilación o no, lo que resulta claro es que, durante estas primeras décadas del siglo XIX, la sociedad vivió el desafío de encontrarse ante un Estado que le exigía nuevas muestras de obediencia similares y diferentes a las requeridas en el antiguo régimen.

\section{LISTA DE REFERENCIAS}

Acta de Independencia de 1813-Nariño (1902). Boletín de Historia y Antigüedades, 1(14). Álvarez White, M. C. (1986). Chiquinquirá, arte y milagro. Bogotá: MAM.

Anderson, B. (1993). Comunidades imaginadas. Reflexiones sobre el origen y la difusión del nacionalismo. México. Fondo de Cultura Económica.

Annino, A. y Guerra, F-X. (2005). Inventando la nación: Iberoamericana, siglo XIX. México: Fondo de Cultura Económica.

Beck, H. (2017). El acontecimiento entre el presente y la historia. Desacatos, 55, 44-59. DoI: https://doi.org/10.29340/55.1803

Blanco, J. F. y Azpurua, R. (1876). Documentos para la historia y vida pública del Libertador (t. x). Caracas: Ediciones de la Presidencia de la República.

Bolívar, S. (2016). Obras completas: escritos de Bolivar de 1820 a 1822 (t. III). Bucaramanga/Cali/Bogotá/Caracas: Fundación para la Investigación y la Cultura-FICA. Burke, P. (2003). La fabricación de Luis XIV. San Sebastián: Nerea. Burke, P. (2006). ¿Qué es historia cultural? Barcelona: Paidós.
Burkholder, M. A. (1984). De la impotencia a la autoridad: la corona española y las audiencias en América 1687-1808. México: Fondo de Cultura Económica.

Cabrera Hanna, S. (2019). La "soberanía primitiva" y las proclamas de los municipios en el Distrito del Sur durante la crisis de la Gran Colombia de 1826. Historia Crítica, 71, 3-23. Dor: https://doi.org/10.7440/histcrit71.2019.01

Chartier, R. (1993). Libros, lecturas y lectores en la Edad Moderna. Madrid: Alianza Universidad.

Chartier, R. (1996). Poderes y límites de la representación. Marín, el discurso y la imagen. En Escribir las prácticas. Foucault, de Certeau, Marín (pp. 73-101). Argentina: Ediciones Manantial.

Chartier, R. (2005a). La nueva historia cultural. En El presente del pasado: escritura de la historia, historia de lo escrito (pp. 3-38). México: Universidad Iberoamericana.

Chartier, R. (2005b). El orden de los libros. Lectores, autores, bibliotecas en Europa entre los siglos XIV y XVIII. Barcelona: Gedisa.

Chicangana-Bayona, Y. A. (2009a). La Independencia en el arte y el arte en la Independencia. Bogotá: Ministerio de Educación Nacional/Colección Bicentenario.

Chicangana-Bayona, Y. A. (2009b). La Campaña del Sur (1813-1816) en las telas de José María Espinosa Prieto. Historia y Sociedad, 17, 69-95. Recuperado de https:// revistas.unal.edu.co/index.php/hisysoc/article/view/20443

Chicangana-Bayona, Y. A. (2011). Historia pintada: las imágenes sobre la independencia colombiana siglos XIX-Xx. En 200 años de la Independencia. Las culturas políticas y sus legados (pp. 525-554). Medellín: Universidad Nacional de Colombia.

Colmenares, G. (1997). Las convenciones contra la cultura: ensayos sobre historiografía hispanoamericana del siglo XIX. Bogotá: Tercer Mundo Editores/Universidad del Valle/Banco de la República/Colciencias.

Cortés Guerrero, J. D. (2014). Las discusiones sobre el patronato en Colombia en el siglo xix. Historia Crítica, 52, 99-122. DoI: https://doi.org/10.7440/histcrit52.2014.05 Earle, R. (2011). La iconografía de la Independencia en la Nueva Granada. En H. Calvo-Stevenson y A. Meisel-Roca (eds.), Cartagena de Indias en la Independencia (pp. 541-598). Cartagena: Banco de la República.

Echeverri, M., Ortega, F. A. y Straka, T. (2018). La invención de la república: la Gran Colombia. Anuario Colombiano de Historia Social y de la Cultura, 45(2), 17-31. Dor: https://doi.org/10.15446/achsc.v45n2.71025

Elliott, J. H. (2010). Una Europa de monarquías compuestas. En España, Europa y el mundo de ultramar (1500-1800) (pp. 55-87). Madrid: Editorial Taurus. 
Fajardo de Rueda, M. (1999). La jura al rey Carlos IV en Nueva Granada. Anales del Instituto de Investigaciones Estéticas, 21(74-75), 195-209. DoI: https://doi.org/10.22201/ iie.18703062e.1999.74-75.1879

Farré, J. (2008). Pedagogía de virreyes y arcos de triunfo en la Nueva España a finales del siglo XVII. Destiempos, 3(14), 262-273.

Freeberg, D. (1998). El poder de las imágenes. Madrid: Ediciones Cátedra.

Geertz, C. (1999). Negara: el Estado-teatro en el Bali del siglo XIX. Barcelona: Paidós.

Gloël, M. (2014). La formación de la monarquía hispánica como monarquía compuesta. Revista Chilena de Estudios Medievales, 6, 11-28. Recuperado de http://revistas.ugm.cl/index.php/rcem/article/view/33

Gutiérrez Ardila, D. (2017). El Reino frente al Rey. Reconquista, pacificación, restauración. Nueva Granada (1815-1819). Bogotá: Universidad Externado de Colombia.

Henao Vanegas, B. E. (2010). A propósito de la relación ciencias sociales-tiempo. Revista Educación y Pedagogía, 14(34), 113-118. Recuperado de https://revistas.udea. edu.co/index.php/revistaeyp/article/view/5925

Hera, A. de la (1992). Iglesia y corona en la América española. Madrid: Mapfre.

Herrera Ángel, M. (2014). Ordenar para controlar: Ordenamiento espacial y control político en los neogranadinos, siglo XVIII. Llanuras del Caribe y en los Andes centrales. Bogotá: Ediciones Uniandes.

König, H-J. (1994). En el camino hacia la nación. Nacionalismo en el proceso de la formación del Estado y la nación de la Nueva Granada, 1750-1856. Bogotá: Editorial del Baco de la República.

Lomné, G. (1993). Las ciudades de la Nueva Granada: teatro y objeto de los conflictos de la memoria política (1810-1830). Anuario Colombiano de Historia Social y de la Cultura, 21, 114-135. Recuperado de https://revistas.unal.edu.co/index.php/achsc/ article/view/34653

Lomné, G. (2003). El “espejo roto" de la Colombia bolivariana (1820-1850). Anuario de Estudios Bolivarianos, 9(10), 125-151.

Lomné, G. (2009). De la República y otras repúblicas: la regeneración de un concepto. En J. Fernández Sebastián (dir.), Diccionario político y social del mundo iberoamericano. La era de las revoluciones, 1750-1850 (pp. 1306-1321). Madrid: Fundación Carolina/Sociedad Estatal de Conmemoraciones Culturales/Centro de Estudios Políticos y Constitucionales.

Londoño Botero, R. (2009). La Virgen de Chiquinquirá: símbolo de identidad nacional. Revista Colombiana de Sociología, 32(1), 83-94
Lux Martelo, M. (2014). Mujeres patriotas y realistas entre dos órdenes. Discursos, estrategias y tácticas en la guerra, la política y el comercio (Nueva Granada, 1790-1830). Bogotá: Uniandes.

Majluf, N. (2013). De cómo reemplazar a un rey: retrato, visualidad y poder en la crisis de la independencia (1808-1830). Histórica, 37(1), 73-108. Recuperado de http:// revistas.pucp.edu.pe/index.php/historica/article/view/7642

Molino García, R. del (2007). Griegos y romanos en la Primera República Colombiana. La Antigüedad Clásica en el pensamiento emancipador neogranadino (1810-1816). Bogotá: Academia Colombiana de Historia.

Mujica Pinilla, R. (2001). Rosa Limensis. Mística, política e iconografía en torno a la patrona de América. Lima: Banco Central de Reserva del Perú/Fondo de Cultura Económica/IFEA.

Murillo de Carvalho, J. (1997). La formación de las almas. El imaginario de la República del Brasil. Bernal: Editorial UNQ.

Museo Nacional de Colombia (ed.) (2010). Las historias de un grito. Doscientos años de ser colombianos. Bogotá: Museo Nacional de Colombia.

Novena al Santísimo Corazón de Jesús (1739). Sacada de las solidadas prácticas de un librito con título Theosoro escondido en corazón de Jesús, por un Devoto del mismo corazón. Sta. Fe de Bogotá: Imprenta de la Compañía de Jesús.

Novena de la Santísima virgen, y madre de Dios del Carmen, María Santísima (1778). Sácala a la luz la congregación de la corona de Nuestra Señora del Carmen, sita en el Colegio de San Alberto a las Sras. Devotas y congregados. Con licencia. Santafé: impresa en Sevilla en la Imprenta de las Siete Revueltas.

Pacheco, J. M (1971). Historia eclesiástica. En Extensa de Colombia (t. I). Bogotá: Academia Colombiana de Historia.

Panizza, O. (1972). Inmaculada concepción de los Papas. Argentina: Editorial ALfA.

Pérez Pérez, M. C. (2015) Las imágenes de culto en la legislación eclesiástica del Virreinato de la Nueva Granada. Relaciones Estudios de Historia y Sociedad, 36(144), 55-82. DoI: http://dx.doi.org/10.24901/rehs.v36i144.44

Pérez Vejo, T. (2003). La construcción de las naciones como problema historiográfico: el caso del mundo hispánico. Historia Mexicana, 53(2), 275-311. Recuperado de https://historiamexicana.colmex.mx/index.php/RHM/article/view/1449

Restrepo, J. M. (1858). Historia de la revolución de la República de Colombia en la América Meridional (4 tt.). Benanzon Imprenta de José Joaquín.

Rey-Márquez, J. R. (2010). Republicanos de la iconografía nacional. En Las historias de un grito. Doscientos años de ser colombianos. Exposición conmemorativa del Bicentenario (pp. 2-36). Bogotá: Museo Nacional de Colombia. 
Rodríguez Moya, I. y Mínguez Cornelles, V. (2012). Cultura simbólica y fiestas bor-

OTRAS FUENTES

bónicas en Nueva Granada. De las exequias de Luis I (1724) a la proclamación de Fernando VII (1808). Revista CS, 9, 115-143. Recuperado de https://dialnet.unirioja.es/servlet/articulo?codigo $=4968489$

Rubial García, A. (2001). La santidad controvertida. Hagiografía y conciencia criolla alrededor de los venerables no canonizados de Nueva España. México: Fondo de Cultura Económica.

Salazar Baena, V. (2017). El cuerpo del rey: poder y legitimación en la monarquía hispánica. Fronteras de la Historia, 22(2), 140-168. DoI: https://doi. org/10.22380/20274688.109

Sanz, A. (1950). Las cruces rosadas. Argensola, 3, 247-260.

Saranyana, J-I. (2008). Debates teológicos latinoamericanos en los comienzos de la era republicana (1810-1830). Anuario de Historia de la Iglesia, 17, 233-252. Recuperado de https://revistas.unav.edu/index.php/anuario-de-historia-iglesia/article/ view/9951

Sebastián, S. (1985). Contrarreforma y barroco. Madrid: Alianza.

Toro Jaramillo, I. D. (2008). Clero insurgente y clero realista en la revolución colombiana de la independencia. Anuario de Historia de la Iglesia, 17, 119-136. Recuperado de https://revistas.unav.edu/index.php/anuario-de-historia-iglesia/article/ view/9974

Vaifas, R, (1996). De la historia de las mentalidades a la historia cultural. Anuario Colombiano de Historia Social y de la Cultura, 23, 219-233. Recuperado de https:// revistas.unal.edu.co/index.php/achsc/article/view/16471

Vanegas Carrasco, C (2012). Iconografía de Bolívar: revisión historiográfica. Ensayos. Historia y Teoría del Arte, 22, 113-134. Recuperado de https://revistas.unal.edu.co/ index.php/ensayo/article/view/46166

Vences Vidal, M. (2009). Manifestaciones de la religiosidad popular en torno a tres imágenes originarias. La unidad del ritual y la diversidad formal. Latinoamericana, 49, 97-126. DoI: http://dx.doi.org/10.22201/cialc.24486914e.2009.49.57427

Vera Prada, I. (2004). Religión, imaginarios nacionales y ritualización como forma de legitimación del orden público postindependentista en Colombia, 1821-1826. Documento Ceso, 67, 1-5.

Villegas, J. (1997). Colombia. Enfrentamiento Iglesia-Estado, 1819-1887. Medellín: Universidad de Antioquia.

Warner, M. (1991). Tú solo entre las mujeres: el mito y el culto de la Virgen María. Madrid: Taurus Humanidades, 1991

\section{Archivos}

AgN Archivo General de la Nacional, Bogotá-Colombia.

AHA Archivo Histórico de Antioquia, Medellín-Colombia. 